\title{
Long and Midterm Effect of Conservation Agriculture on Soil Properties in Dry Areas of Morocco
}

\author{
Malika Laghrour, ${ }^{1,2}$ Rachid Moussadek, ${ }^{2}$ Rachid Mrabet, ${ }^{2}$ Rachid Dahan, ${ }^{2}$ \\ Mohammed El-Mourid, ${ }^{3}$ Abdelmajid Zouahri, ${ }^{2}$ and Mohamed Mekkaoui ${ }^{1}$ \\ ${ }^{1}$ Groupe Physicochemistry of Materials, Nanomaterials and Environment, Faculty of Sciences, Mohammed V University, \\ Ibn Battuta Avenue, P.O. Box 1014, Rabat, Morocco \\ ${ }^{2}$ National Institute of Agricultural Research (INRA), BP 6356, Rabat, Morocco \\ ${ }^{3}$ International Center for Agricultural Research in the Dry Areas (ICARDA), Rabat Instituts, North-Africa Platform, \\ P.O. Box 6299, 10112 Rabat, Morocco
}

Correspondence should be addressed to Malika Laghrour; laghrour.malika@gmail.com and Rachid Moussadek; rachidmoussadek@yahoo.fr

Received 25 August 2016; Revised 1 November 2016; Accepted 2 November 2016

Academic Editor: Artemi Cerda

Copyright (C) 2016 Malika Laghrour et al. This is an open access article distributed under the Creative Commons Attribution License, which permits unrestricted use, distribution, and reproduction in any medium, provided the original work is properly cited.

In Morocco, conservation agriculture, particularly no tillage systems, has become an alternative strategy to mitigate land degradation caused by conventional tillage in semiarid to arid regions. This paper is based on behaviour to tillage treatments of two Vertisols in Morocco. After 11 years of testing, soil organic matter content results showed a significant difference $(P<0.05)$ only at soil surface $(0-10 \mathrm{~cm})$ in favour of no tillage and a variation of $30 \%$ at this depth. The results obtained after 32 years of testing showed a significant soil profile difference $(P<0.05)$, up to $40 \mathrm{~cm}$ under no tillage compared to conventional tillage, and a variation of $54 \%$ at $5-10 \mathrm{~cm}$. For total nitrogen, there was no significant effect between no tillage and conventional tillage at the soil surface after 11 years unlike the result obtained after 32 years. There are no significant differences in bulk density between tillage treatments at soil surface for both sites. The measurement of soil structural stability showed a significant effect $(P<0.05)$ for all three tests and for both sites. This means that no tillage helped Vertisols to resist different climatic constraints, preserving environmental soil quality.

\section{Introduction}

Soil organic matter (SOM) is a fundamental attribute of soil quality [1-4]. The presence of sufficient quantities of SOM in the soil changes the nutrients and physical properties of soil considerably [5-10]. It improves soil fertility [11], reinforces the cohesion between mineral particles, and contributes to improved water infiltration and good structure. SOM plays an important role in soil protection against drought, erosion, and runoff and ensures sustainable food production [12]. However, a fear of a excessive loss of SOM has been expressed in recent decades in the world [13]. This loss of SOM is of natural and particularly anthropogenic origin, due to the use of inappropriate soil management techniques. Regretfully, the farmers believe in these inappropriate techniques, such as deep tillage, and are unaware of the fact that, in the long term, these agricultural practices are contrary to sustainable agriculture. Some recent studies have shown that intensive plowing of the soil exposes SOM to rapid mineralisation, reduces soil fertility, destroys the aggregates, and deteriorates aeration and moisture conditions. Additionally, this plowing leads to increased soil erosion and crop residues can reduce soil loss [14-19].

For this purpose, the adoption of a strategy to protect natural resources should be an internationally strong preoccupation. Bessam and Mrabet [20], Mrabet [21], Moussadek et al. [22], and Sheehy et al. [23] have revealed, in several studies, the importance of adopting conservation agriculture, including no tillage (NT) as an alternative remedy for addressing this alarming situation. In terms of agricultural 
technology, NT is considered one of the greatest revolutions of this century. This practice is based on direct seeding, where the residues from antecedent cultures are left on the soil surface to ensure the accumulation of carbon and its sequestration in different types of climate in the world [2426].

In Morocco, as in many parts of the world, adaptation to the NT system has become an alternative strategy, to mitigate land degradation in semiarid to arid regions through carbon accumulation on the soil surface. The organic matter under most Moroccan regions is less than 2\%, and after ten years, the average loss of soil organic matter due to tillage was estimated to be $30 \%$ [25]. Generally, there are many benefits of the NT vis-a-vis climate hazards in semiarid and arid regions (drought, erosion, etc.). NT's usefulness and its importance as a conservative technique for soil quality have prompted Moroccan researchers at the National Institute for Agricultural Research (INRA) to adopt NT immediately. This began in the Jemaat Shaim region of Morocco in 1983 and then at the experimental station of Sidi El Aidi Chaouia, and finally NT was implemented in the experimental station of Merchouch in Zaer-Rabat at 2004 [27]. The objective of this work is to study the long- and medium-term effects of tillage modes, that is, NT and conventional tillage (CT), on pertinent soil quality:

(i) Soil organic matter content profile.

(ii) Structural stability and bulk density of the soil.

(iii) Total nitrogen and carbon/nitrogen ratio $(\mathrm{C} / \mathrm{N})$.

\section{Materials and Methods}

2.1. Study Areas. Two experimental sites of Vertisol were chosen for this study (Figure 1).

The first site (site I) is located at the experimental station of Merchouch INRA. This experimental field is attached to the Regional Center of Agricultural Research in Rabat (RCARR). It is located in the Central Plateau of the rural commune of Merchouch, circle of Rommani, Province of Khemisset, about $68 \mathrm{~km}$ to the southeast of Rabat and $16 \mathrm{~km}$ to the North-West of Rommani. It is crossed by the secondary road $\mathrm{N}^{\circ} 218$ that divides it into two parts: northern and southern part. The geographical coordinates of this site are as follows: altitude: 339 ; longitude: $06^{\circ} 71^{\prime}$ west; latitude: $33^{\circ} 60^{\prime}$ north.

The second experimental site (site II) is located at $12 \mathrm{~km}$ North-East of the village of Jemaat Shaim (in Safi region) and $40 \mathrm{~km}$ from the coast of the Atlantic ocean $\left(\mathrm{N} 32^{\circ} 40^{\prime} \times 10^{\circ} 0^{\prime}\right.$, $170 \mathrm{~m})$. This site is characterized by an annual precipitation ranging from 147.2 to $527.8 \mathrm{~mm}$ with a mean of 30 years estimated at $300 \mathrm{~mm}$. The temperature reaches $-4^{\circ} \mathrm{C}$ in December and January and $47^{\circ} \mathrm{C}$ in July and August. The annual averages of rainfall and temperature in 2014-2015 for two sites are shown, respectively, in Figure 2.

This figure shows that the Jemaat Shaim site is characterized by a higher annual temperature and less rainfall than those recorded in the Merchouch site. The climate in the first site is semiarid, while the climate in the second site is

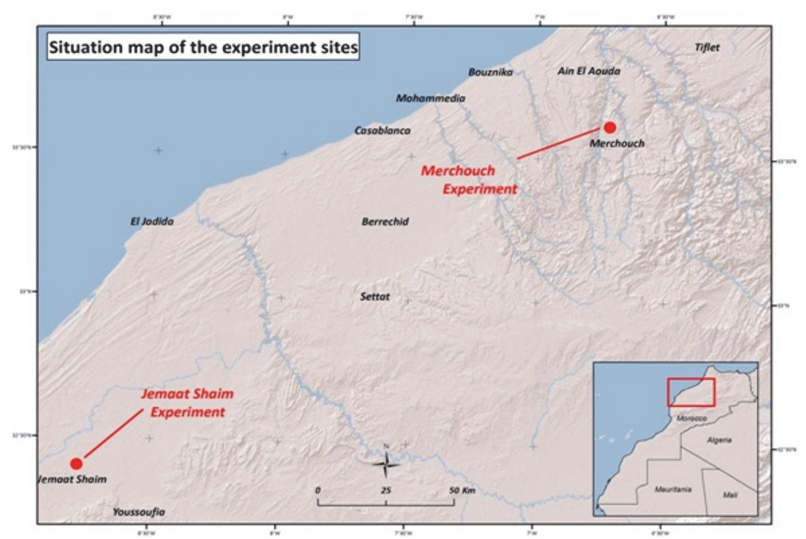

FIGURE 1: Maps showing the two sites.

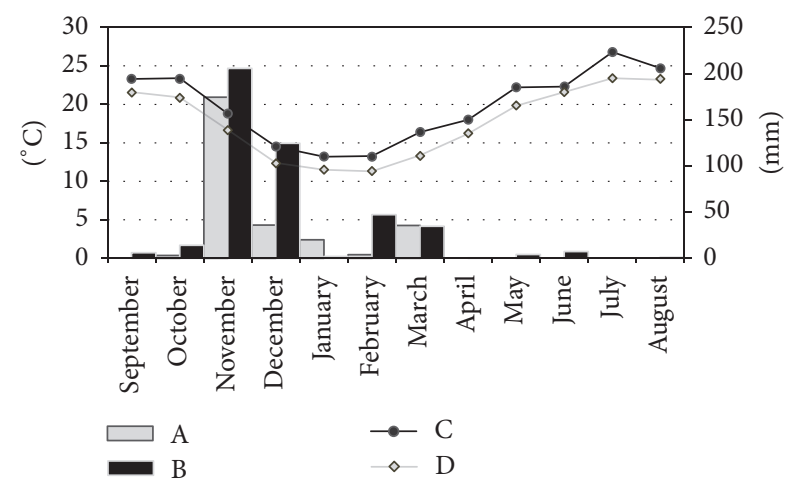

FIgURE 2: Mean temperatures and precipitations during 2014-2015 for both study sites in Morocco. (A) mean precipitations (mm) for 2nd site; (B) mean precipitations ( $\mathrm{mm}$ ) for 1st site; (C) mean temperatures $\left({ }^{\circ} \mathrm{C}\right)$ for 2 nd site; $(\mathrm{D})$ mean temperatures $\left({ }^{\circ} \mathrm{C}\right)$ for 1 st site.

classified as semiarid to arid. According to the particle size results shown in Table 1 , in the first site, soil has more than $50 \%$ of clay in $0-80 \mathrm{~cm}$ depth, and in the second site, soil clay quantity decreased less than $50 \%$ in depth horizon.

2.2. Methodology. The plots of the two experimental sites were differentiated with two tillage treatments: CT and NT. The first treatment consists in a conventional tillage (plowing up to $30 \mathrm{~cm}$ deep) followed by shallow tillage $(10-15 \mathrm{~cm})$. The objective was to prepare a fine seedbed and to bury plant residues. In contrast to the second treatment, this one comprises a single operation. It was realised with a special NT drill that consists of an opening of $2-3 \mathrm{~cm}$ from the ground to put the seeds at $5 \mathrm{~cm}$ depth. Both sites are based on the agricultural rotation cereals/legumes. This rotation was started in the second site since 2009.

2.3. Soil Measurements. In order to study the impact of NT and CT on the main components of soil quality, different methods of soil sampling were followed according to our objectives and parameters that used in study measurement.

For the first experiment, thirty-six samples have been collected from the soil surface, including the following 
TABLE 1: Soll texture characteristics at the soil profile for the both sites.

\begin{tabular}{|c|c|c|c|c|c|c|}
\hline \multirow{2}{*}{ Field } & \multirow{2}{*}{ Duration } & \multirow{2}{*}{ Soil depth $(\mathrm{cm})$} & \multicolumn{3}{|c|}{ Texture (\%) } & \multirow{2}{*}{ Texture } \\
\hline & & & Clay & Slit & Sand & \\
\hline \multirow{3}{*}{$\begin{array}{l}\text { Site I } \\
\text { Merchouch }\end{array}$} & \multirow{3}{*}{11 years } & $0-10$ & 54.5 & 32.3 & 11.2 & Clay \\
\hline & & $0-20$ & 50.0 & 37.3 & 12.7 & Clay \\
\hline & & $20-80$ & 52.5 & 35.1 & 12.4 & Clay \\
\hline \multirow{8}{*}{$\begin{array}{l}\text { Site II } \\
\text { Jemaat Shaim }\end{array}$} & \multirow{8}{*}{32 years } & $0-2.5$ & 56.5 & 32.23 & 11.38 & Clay \\
\hline & & $2.5-5$ & 46.2 & 30.95 & 22.9 & Clay \\
\hline & & $5-10$ & 45 & 22.9 & 32.1 & Clay \\
\hline & & $10-20$ & 42.1 & 21.01 & 36.91 & Clay \\
\hline & & $20-30$ & 39.7 & 23.32 & 37.02 & Clay/loam clay \\
\hline & & $30-40$ & 31.4 & 33.24 & 35.05 & Loam clay \\
\hline & & $40-60$ & 42.1 & 21.01 & 36.82 & Clay \\
\hline & & $60-80$ & 42 & 20.21 & 36.84 & Clay \\
\hline
\end{tabular}

TABLE 2: Summary of soil samples collected from two sites.

\begin{tabular}{lcccccc}
\hline Field & Sampling time & Rotation & Crops & Total samples & $\begin{array}{c}\text { Number of samples } \\
\text { For chemical analysis }\end{array}$ & For physical analysis \\
\hline Site I & May 26, 2015 & Cereals/legumes & Soft wheat & 36 & 24 & 12 \\
\hline Site II & June 23, 2015 & Cereals/legumes & Chickpea & 104 & 80 & 24 \\
\hline
\end{tabular}

depths: $(0-10 \mathrm{~cm})$ to $(10-20 ; 20-40 ; 40-60 \mathrm{~cm})$, based on three replicates for each parameter just for SOM analysis. For this site, the samples collection was in May 26, 2015. The plots were based on cereal (soft wheat). In the oldest field experiment, sampling concerned eight depths, 0-2.5; $2.5-5 ; 5-10 ; 10-20 ; 20-30 ; 30-40 ; 40-60$; and $60-80 \mathrm{~cm}$, for five replicates. There were twenty-four samples for the soil physical analysis (structural stability and BD) with 3 replications, for each analysis considering only two depths (0-10 and 10-20 cm). Samples collection was performed on June 23, 2015, on two plots of chickpea. The summary of soil samples collected from two sites is presented in Table 2 .

\subsection{Analytical Methods}

2.4.1. Organic Matter. The collected samples were dried aerobically and sieved through $0.2 \mathrm{~mm}$ in order to determinate soil organic carbon content. These contents were estimated using the modified method of Walkley and Black [28] which is based on the principle that the potassium dichromate oxidizes the contained carbon in the soil. Potassium dichromate changes its colour depending on the amount of reduced products; this change in colour can be compared to the amount of organic carbon in the soil. We deduce the organic matter content by multiplying the carbon content by 1.724 .

2.4.2. Total Nitrogen. TN was determined by the modified Kjeldahl method [29]. The mineralisation of soil organic nitrogen as ammonium sulfate was performed in the presence of concentrated sulfuric acid. By stripping to water vapor, there is liberation of ammonia in an alkaline medium and its dosage is performed by acidimetry.
2.4.3. Dry Bulk Density (BD). The measure of $\mathrm{BD}$ was performed only at the soil surface $(0-10 \mathrm{~cm})$, using a cylinder (core sample). The samples were weighed before and after passing through the oven at $105^{\circ} \mathrm{C}$ for 48 hours. This measure is in $\mathrm{g} \cdot \mathrm{cm}^{-3}$ and is evaluated according to the method of Grossman and Reinsch [30].

2.4.4. Aggregate Stability. The soil aggregate stability estimates the capacity of a soil to retain its structure when it is subjected to different constraints. It is determined by the method proposed by Le Bissonnais [31], which combines three tests describing the behaviour of the soil under different climatic and water conditions. Le Bissonnais methods consist in subjecting soil sampling to 3 treatments:

(i) Fast wetting by immersion.

(ii) Wetting slow capillary.

(iii) Mechanical disaggregation agitation after rewetting.

Moreover, the soil organic matter is the main factor of cohesion between soil aggregates of these three tests.

2.5. Statistical Analysis. Statistical analysis of the data have been realised for the purpose to study the effect of tillage treatments (NT and CT) on soil physical and chemical properties. For this, our results measurements were performed by comparing their means according to the $t$-test (Student's $t$ test). The software used for statistical processing is the SPSS STATISTICS 21. 
TABLE 3: Tillage effect on SOM content (mean \pm standard deviation).

\begin{tabular}{|c|c|c|c|c|}
\hline \multirow{2}{*}{ Field } & \multirow{2}{*}{ Soil depth $(\mathrm{cm})$} & \multicolumn{2}{|c|}{ Organic matter content $\left(\mathrm{g} \cdot \mathrm{Kg}^{-1}\right)$} & \multirow{2}{*}{ CT to NT \% SOM change } \\
\hline & & NT & $\mathrm{CT}$ & \\
\hline \multirow{4}{*}{ Site I } & $0-10$ & $22.23 \pm 0.20 \mathrm{a}^{*}$ & $17.13 \pm 0.25 b^{*}$ & 30 \\
\hline & $10-20$ & $19.11 \pm 0.03 \mathrm{a}$ & $17.38 \pm 0.12 \mathrm{a}$ & 10 \\
\hline & $20-40$ & $17.23 \pm 0.10 \mathrm{a}$ & $16.43 \pm 0.05 a$ & 5 \\
\hline & $40-60$ & $15.80 \pm 0.04 \mathrm{a}$ & $15.36 \pm 0.03 a$ & 3 \\
\hline \multirow{9}{*}{ Site II } & $0-2.5$ & $19.12 \pm 0.47 \mathrm{a}$ & $13.02 \pm 0.21 b$ & 47 \\
\hline & $2.5-5$ & $15.38 \pm 0.27 \mathrm{a}$ & $10.74 \pm 0.14 b$ & 44 \\
\hline & $5-10$ & $15.62 \pm 0.06 a$ & $10.06 \pm 0.17 b$ & 54 \\
\hline & $0-10$ & $16.44 \pm 0.22 \mathrm{a}$ & $10.97 \pm 0.17 b$ & 50 \\
\hline & $10-20$ & $12.68 \pm 0.06 \mathrm{a}$ & $9.42 \pm 0.10 \mathrm{~b}$ & 35 \\
\hline & $20-30$ & $12.48 \pm 0.09 \mathrm{a}$ & $9.58 \pm 0.10 b$ & 30 \\
\hline & $30-40$ & $13.22 \pm 0.17 \mathrm{a}$ & $9.80 \pm 0.10 \mathrm{~b}$ & 35 \\
\hline & $40-60$ & $11.18 \pm 0.06 \mathrm{a}$ & $9.440 \pm 0.17 \mathrm{a}$ & 19 \\
\hline & $60-80$ & $10.20 \pm 0.10 \mathrm{a}$ & $12.94 \pm 0.22 \mathrm{a}$ & -21 \\
\hline
\end{tabular}

${ }^{*}$ In the same row, the values followed by different letters are significantly different within each study site according to Student's test $(P<0.05)$.

\section{Results and Discussion}

3.1. Impact of Tillage Systems on Soil Organic Matter Content. The importance of SOM is its positive influence on many physical and chemical properties of soil. This is why the impact of NT, in which residues of the antecedent culture are not removed and decomposed at soil surface, on SOM content has been studied by different authors for different climatic conditions and different types of soils. But no studies have been made on SOM of Vertisols after 11 and 32 years under NT.

For the first site (Table 3), it was found that the SOM content is higher under NT than CT with a variation of $30 \%$. The statistical analysis shows a significant difference only in $0-10 \mathrm{~cm}$ between tillage systems $(P$ value $=0.01<0.05)$ and no significant effect in the soil profile (from 10 to $60 \mathrm{~cm}$ of depth) under NT. This result is similar to that obtained by Moussadek et al. [22], and Laghrour et al. [32], for the same study field after seven and ten years of trial, respectively. This is also confirmed by Angers et al. [33] and Blanco-Canqui and Lal [34], who have also shown a high SOM content at $0-10 \mathrm{~cm}$ layer under NT compared to CT. Moreover, Hassink [35] and Shi et al. [36] found that, with the depth, the values were similar between the two tillage treatments. Wander et al. [37], Guzmane et al. [38], and Sparrow et al. [39] reported that, under NT, soil organic carbon contents are strongly stratified at soil surface and decrease rapidly with depth.

Based on student test, our results for the second site (Table 3) show significant differences in the soil profile, at depths up to $40 \mathrm{~cm}$ (from soil surface to $40 \mathrm{~cm}$ of depth) between the two tillage treatments. This result is contrary to Angers and Eriksen-Hamel [40] and Syswerda and coll. [41] who showed that the difference between NT and CT is not observed over $30 \mathrm{~cm}$ in depth. However, an important accumulation was recorded under NT for the 5-10 cm layer compared to those recorded for the other two layers of the soil surface $(0-2.5 \mathrm{~cm}$ and $2.5-5 \mathrm{~cm})$, where the variation of SOM between tillage treatments was $54 \%, 47 \%$, and $44 \%$, respectively. However, Liu et al. [42] observed after 17 years under NT a greater content of organic carbon in $0-5 \mathrm{~cm}$ layer than $5-10 \mathrm{~cm}$ layer. The results of these authors were statistically significant only for $0-10 \mathrm{~cm}$ of depth and there was no significant difference for the other layers of depth from 10 to $60 \mathrm{~cm}$. They added that, in deep layers, the organic carbon content was higher in CT versus NT contrary to our results obtained after 11 years of trial. The different variation of SOM obtained in the profile can be explained by the type of soil and this is confirmed by Paton [43] and Kovda et al. [44], who showed that the Vertisols are characterized by the presence of slickensides and deep cracks. In another study, the significant effect of these results up to $40 \mathrm{~cm}$ deep under NT is due to the accumulation of organic carbon at soil surface $[45,46]$ and its long-term distribution in the deeper layers. These results are similar to those obtained by Dimassi et al. [47].

3.2. Impact of Tillage Systems on Total Nitrogen and C/N Ratio. Eighty-five to 95 percent of TN consists of organic nitrogen. This latter becomes available for plants by mineralisation related to the activity of microorganisms. The SOM is the main soil nitrogen reserves.

For the first site, the TN is higher at soil surface under NT compared to CT (Table 4). But this result shows no significant difference between tillage treatments. Similar results were found by Angers et al. [33] and Blanco-Canqui and Lal [34]. This is probably explained by the lack of SOM accumulated on the soil surface after 11 years of experiment.

After 32 years, the great values of the TN are measured under NT with significant differences between the two tillage treatments from the surface $(0-2.5,2.5-5$, and 5-10 cm) up to $10-20 \mathrm{~cm}$ deep layer (Table 4 ). The values obtained for the rest of profile have no significant effect. This significant NT effect seems influenced by the accumulation of organic matter content and adoption period of NT system under different conditions. This is clearly visible and understood in several 
TABLE 4: Tillage treatments effect on total nitrogen (mean \pm standard deviation) and on $\mathrm{C} / \mathrm{N}$ ratio.

\begin{tabular}{|c|c|c|c|c|c|}
\hline \multirow{2}{*}{ Field } & \multirow{2}{*}{ Soil depth $(\mathrm{cm})$} & \multicolumn{2}{|c|}{ Total nitrogen $\left(\mathrm{g} \cdot \mathrm{Kg}^{-1}\right)$} & \multicolumn{2}{|c|}{$\mathrm{C} / \mathrm{N}$} \\
\hline & & NT & CT & NT & $\mathrm{CT}$ \\
\hline Site I & $0-10$ & $1.20 \pm 0.02 \mathrm{a}^{*}$ & $1.20 \pm 0.01 \mathrm{a}^{*}$ & 10.75 & 8.28 \\
\hline \multirow{8}{*}{ Site II } & $0-2.5$ & $1.22 \pm 0.01 \mathrm{a}$ & $0.92 \pm 0.01 b$ & 9.02 & 8.31 \\
\hline & $2.5-5$ & $1.08 \pm 0.01 \mathrm{a}$ & $0.94 \pm 0.01 b$ & 8.23 & 6.63 \\
\hline & $5-10$ & $1.10 \pm 0.01 \mathrm{a}$ & $0.94 \pm 0.01 b$ & 8.28 & 6.25 \\
\hline & $10-20$ & $1.20 \pm 0.01 \mathrm{a}$ & $0.94 \pm 0.01 b$ & 6.15 & 5.87 \\
\hline & $20-30$ & $1.04 \pm 0.01 \mathrm{a}$ & $0.98 \pm 0.00 \mathrm{a}$ & 6.98 & 6.67 \\
\hline & $30-40$ & $0.94 \pm 0.01 \mathrm{a}$ & $0.90 \pm 0.01 \mathrm{a}$ & 8.24 & 6.31 \\
\hline & $40-60$ & $0.88 \pm 0.01 \mathrm{a}$ & $0.98 \pm 0.01 \mathrm{a}$ & 7.39 & 5.61 \\
\hline & $60-80$ & $0.88 \pm 0.01 \mathrm{a}$ & $0.88 \pm 0.01 \mathrm{a}$ & 6.80 & 8.64 \\
\hline
\end{tabular}

* In the same row, the means followed by the same letter were not significantly different at $P<0.05$ between tillage treatments.

research works. After 5 years under NT tests, Testa et al. [48] indicated a significant difference at soil surface $(0-7.5 \mathrm{~cm})$. Significant differences were also found after 9 years of trial at $0-12.5 \mathrm{~cm}$ [49] and after 11 years at $0-17.5 \mathrm{~cm}$ and $20 \mathrm{~cm}$ by Burle et al. [50] and Mrabet et al. [51], respectively.

From these results obtained by several authors, it appears that the TN content is becoming increasingly important with soil depth and depends mainly on the adoption of the NT duration.

The $\mathrm{C} / \mathrm{N}$ ratio is considered as an important soil fertility indicator which can be used to reflect the interaction between SOM and soil TN [52]. The results for the first site (Table 4) showed that soil $\mathrm{C} / \mathrm{N}$ ratio in $0-10 \mathrm{~cm}$ layer was higher under NT than CT. For the second site (Table 4), there is a greater increase in this ratio under NT than CT at the soil profile up to $60 \mathrm{~cm}$ in depth. This result of $\mathrm{C} / \mathrm{N}$ ratio at soil surface in favour of NT can be explained by the residues remaining from the prior crop. In addition, the soil $\mathrm{C} / \mathrm{N}$ ratio declined with depth profile under both tillage treatments. This may be probably due to the clay content, which varies with depth. Some authors reported that high clay content is often associated with organic matter decomposition increases when the $\mathrm{C} / \mathrm{N}$ ratio decreases [53-56].

Similar results were found in favour of NT after 22 years [52], while Mazzoncini et al. [57] did not find a difference of $\mathrm{C} / \mathrm{N}$ ratio between the two tillage systems despite the variations in soil organic carbon and soil total nitrogen.

3.3. Impact of Tillage Systems on Structural Stability. Le Bissonnais [31] defined the structural stability or the stability of the aggregates by the capacity of a soil to maintain its arrangement between the solid and empty particles when exposed to various stresses as they may be of different types and of different intensities. The impacts of soil tillage tools, rain or wetting, are examples of these constraints. Good structural stability reduces crusting and consequently soil losses by runoff and erosion. The effects of tillage treatments on the aggregate stability measured by mean weight diameter are shown in Figure 3.

For the first site, the measurement of the structural stability of soil shows significant effect tillage for all three tests. This means that, after 11 years of testing, Vertisol can resist different climatic constraints, specifically fast wetting. The significance of this test means that the soil can resist brutal rain while the slow-wetting test means that the Vertisol can resist moderate rainfall $[22,58]$. These results are consistent with those obtained by Laghrour et al. [32], for the same experiment study after 10 years. These authors did not find a meaningful result for the mechanical disaggregation test, contrary to our results that showed, after 11 years of experiment, a significant difference between tillage treatments. This means that, after 11 years, the Vertisol of Merchouch can withstand this test, the purpose of which is to test the soil cohesion wet regardless of bursting. Sheehy et al. [23] showed that aggregate stability results for Vertic Cambisol (10 years of experiment) and Eutric Regosol (11 years of experiment) were significantly different between NT and CT at soil surface.

However, for the second site, NT results increased aggregate stability, compared to CT, of between 89 and 30 percent for the depths $0-10 \mathrm{~cm}$ and $10-20 \mathrm{~cm}$, respectively. This great stability recorded at the soil surface shows that, after 32 years under NT, Vertisols are more stable in NT than in CT against the erosion and runoff. In addition, statistical analysis clearly indicates that all tests for $0-10$ and $10-20 \mathrm{~cm}$ of depth are significantly different $(P<0.05)$ between the treatments in favour of NT. These results are contrary to those obtained by Kibet et al. [59], who showed that, after long-term experiment (established in 1981), they found a significant effect for a Sharpsburg silty clay loam soil only at $0-10 \mathrm{~cm}$ under NT compared to other tillage treatments and any significant effect was found at $10-20 \mathrm{~cm}$ of depth between tillage treatments.

Moreover, the significant effect observed for the fastwetting test, which is a destructive test, shows that soil can resist breakdown aggregates [22, 58] and sudden rainfall. However, the results obtained for the slow-wetting test, characterized by a low water gradient and larger air exhaust possibilities, indicate that the NT was able to limit the speed of this wetting. This means that the Vertisol can better withstand moderate rain. A significant effect was also observed for the mechanical disaggregation test after 32 years.

Amézketa [60] showed that the aggregate stability was affected by several factors, with SOM being the most important. Indeed, SOM acts as a binder between the particles and alters the hydrophobicity of the aggregates. Still, numerous 


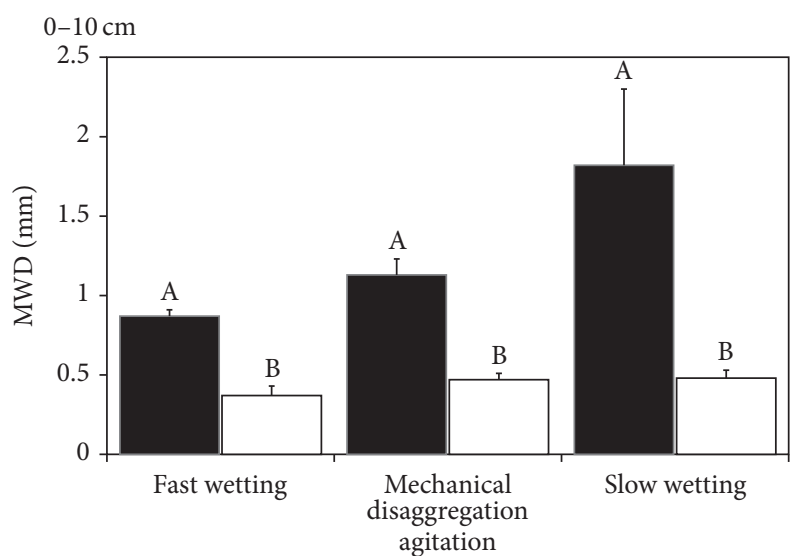

- NT

$\square \mathrm{CT}$

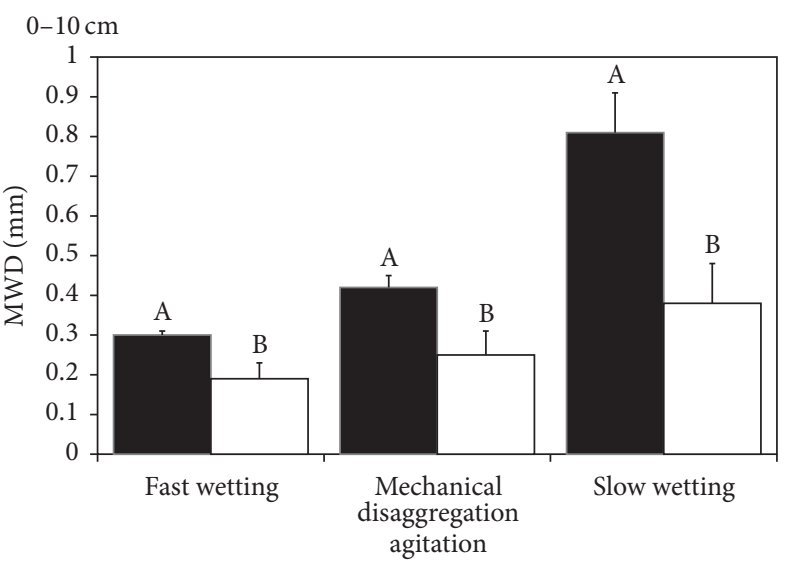

- NT

ㄷ CT

(a)

(b)

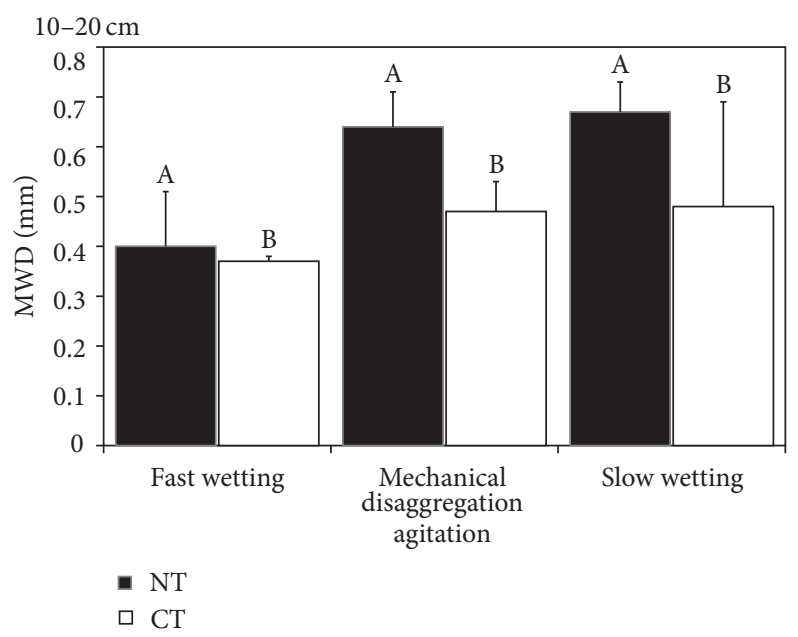

(c)

FIGURE 3: Effect of tillage treatments on structural stability at soil surface for both sits located in Morocco. (a) Mean weight diameter (MWD) for each test of structural stability for the 1 st site at $0-10 \mathrm{~cm}$ of depth; (b and c) mean weight diameter for 2nd site. (b) At 0-10 cm of depth; (c) at $10-20 \mathrm{~cm}$ of depth. Bars represent standard deviation, the difference letters above the column show significant difference between no tillage (NT) and conventional tillage (CT) practices.

studies have related increased structural stability to the accumulation of SOM [61-66]. It is to be noted that, despite the significant effects of the structural stability recorded under NT versus CT, the results indicate low values of MWD ( 0.3 to 0.81 for NT and 0.19 to 0.48 for CT). This finding is likely due to the Vertisol.

After these results, we can say that NT helped to construct a good structure with time, which is highly desirable for sustaining agricultural productivity (it can be beneficial to plant growth) and for preserving environmental quality (it can reduce soil erosion and nutrient losses in runoff) [67].

3.4. Impact of Tillage Systems on Bulk Density. The $\mathrm{BD}$ is one of the most important parameters in studies of soil structure. It allows for the diagnosis of the soil compaction as this density is related to the porosity of the soil. The result (Table 5) indicates no significant effect after 11 years of NT.
TABLE 5: Tillage treatments effect on bulk density (mean \pm standard deviation).

\begin{tabular}{lccc}
\hline \multirow{2}{*}{ Field } & \multirow{2}{*}{ Soil depth $(\mathrm{cm})$} & \multicolumn{2}{c}{ BD $\left(\mathrm{g} \cdot \mathrm{cm}^{-3}\right)$} \\
& & NT & CT \\
\hline Site I & $0-10$ & $1.29 \pm 0.04 \mathrm{a}$ & $1.15 \pm 0.14 \mathrm{a}$ \\
\hline \multirow{2}{*}{ Site II } & $0-10$ & $1.41 \pm 0.07 \mathrm{a}$ & $1.37 \pm 0.22 \mathrm{a}$ \\
& $10-20$ & $1.45 \pm 0.05 \mathrm{a}$ & $1.35 \pm 0.14 \mathrm{a}$ \\
\hline
\end{tabular}

The same result was found after 10 years of trial [32], contrary to Moussadek et al. [22] showing a significant effect of this measure $\mathrm{BD}(\mathrm{CT})<\mathrm{BD}(\mathrm{NT})$ under NT in 2011. This explains that the soil under NT usually becomes more porous and less compacted and thus more water permeable.

The results of the $\mathrm{BD}$ for the second site are presented also in Table 5. The result of this analysis indicates that there 
are no significant differences between the two tillage systems at soil surface $0-10 \mathrm{~cm}(P=0.78 \gg 0.05)$ and $10-20 \mathrm{~cm}$ $(P=0.311>0.05)$. At $0-10 \mathrm{~cm}$, there is a value of $\mathrm{BD}$ under NT (1.41) almost equal to that seen in CT (1.37). For the $10-20 \mathrm{~cm}$ layer, the difference remains. In addition, in comparison with $\mathrm{CT}$, the $\mathrm{BD}$ is higher under NT at three percent in the $0-10 \mathrm{~cm}$ depth and seven percent at $10-20 \mathrm{~cm}$. This probably means that the compaction of Vertisol soil types may decline with a long-term adoption of NT. Similar results were observed under NT in the medium term of a Vertisol [32]. We can also compare our results with those obtained by Liu et al. [42], which indicate that, after 17 years of testing, the BD was higher under NT at soil surface and at $0-30 \mathrm{~cm}$ in depth. The BD of a Cambisol is higher under NT versus CT by $5,3.5$, and 13.9 percent at depths of $0-5$, $5-10$, and 10-20, respectively. The authors found a significant difference $(P<0.05)$ between treatments for $0-10 \mathrm{~cm}$ and $10-20 \mathrm{~cm}$. de Moraes et al. [68] compared the BD of Oxisols under NT to that obtained under CT after 11 (NT11) and 24 years (NT24). These authors found a significant difference in comparing the NT system to that of CT and did not find a significant effect between NT11 and NT24, but the BD was low compared with the NT24 and NT11 (BD NT11 > BD NT24 $>\mathrm{BD}$ CT), while low BD in NT24 was recorded by the CT contributed with a significant difference in the depth 10-20. At this depth, the results obtained can be summarized as follows: BDNT11 > BDCT > BDNT24.

\section{Conclusion}

Among the cultural practices, NT is the subject of sustained attention in recent years. This practice of NT is recently evolved and many observations showed that it has a strong impact on the nature and evolution of SOM that influences a set of chemical properties $(\mathrm{TN}$ and $\mathrm{C} / \mathrm{N}$ ) and physical soil (BD and structural stability). This paper has allowed for studying the effect of NT and CT on the physical and chemical properties of the semiarid to arid regions. The results for the second site of Jemaat Shaim show that, after 32 years of testing, the NT promotes the accumulation of the SOM in the soil surface and in depth up to $40 \mathrm{~cm}$, in contrast to CT. The accumulation at soil surface is confirmed after 11 years of testing in the first site that records significant levels of the SOM at the soil surface. On the one hand, the high content of SOM clearly explains the availability of nutrients as total nitrogen and the stability of the aggregates under NT compared with those who have been intensively tilled. On the other hand, the results obtained under the two tillage treatments can be explained by the duration of this new agricultural practice. This allowed for saying that CT is more susceptible to degradation by erosion and runoff, but under NT soil it has stable aggregates as shown in the test of structural stability.

\section{Competing Interests}

The authors declare that there is no conflict of interests regarding the publication of this paper.

\section{Acknowledgments}

This research is supported by a joint INRA-ICARDA project in integrated natural resources management (INRM project).

\section{References}

[1] V. A. Laudicina, A. Novara, V. Barbera, M. Egli, and L. Badalucco, "Long-term tillage and cropping system effects on chemical and biochemical characteristics of soil organic matter in a mediterranean semiarid environment," Land Degradation and Development, vol. 26, no. 1, pp. 45-53, 2015.

[2] A. Novara, L. Gristina, M. B. Bodì, and A. Cerdà, "The impact of fire on redistribution of soil organic matter on a Mediterranean hillslope under maquia vegetation type," Land Degradation and Development, vol. 22, no. 6, pp. 530-536, 2011.

[3] S. Mukhopadhyay, R. E. Masto, A. Cerdà, and L. C. Ram, "Rhizosphere soil indicators for carbon sequestration in a reclaimed coal mine spoil," Catena, vol. 141, pp. 100-108, 2016.

[4] L. Parras-Alcántara, B. Lozano-García, E. C. Brevik, and A. Cerdá, "Soil organic carbon stocks assessment in Mediterranean natural areas: a comparison of entire soil profiles and soil control sections," Journal of Environmental Management, vol. 155, pp. 219-228, 2015.

[5] T. B. Bruun, B. Elberling, A. de Neergaard, and J. Magid, "Organic carbon dynamics in different soil types after conversion of forest to agriculture," Land Degradation and Development, vol. 26, no. 3, pp. 272-283, 2015.

[6] X. Chen, Z. Duan, and M. Tan, "Restoration affect soil organic carbon and nutrients in different particle-size fractions," Land Degradation \& Development, vol. 27, no. 3, pp. 561-572, 2016.

[7] J. C. de Moraes Sá, L. Séguy, F. Tivet et al., "Carbon Depletion by Plowing and its Restoration by No-Till Cropping Systems in Oxisols of Subtropical and Tropical Agro-Ecoregions in Brazil," Land Degradation and Development, vol. 26, no. 6, pp. 531-543, 2015.

[8] S. P. de Oliveira, N. B. de LaCerdà, S. C. Blum, M. E. O. Escobar, and T. S. de Oliveira, "Organic carbon and nitrogen stocks in soils of northeastern Brazil converted to irrigated agriculture," Land Degradation and Development, vol. 26, no. 1, pp. 9-21, 2015.

[9] M. D. M. Montiel-Rozas, M. Panettieri, P. Madejón, and E. Madejón, "Carbon sequestration in restored soils by applying organic amendments," Land Degradation and Development, vol. 27, no. 3, pp. 620-629, 2015.

[10] L. Deng and Z.-P. Shangguan, "Afforestation drives soil carbon and nitrogen changes in China," Land Degradation and Development, 2016.

[11] X.-B. Du, C. Chen, L.-J. Luo et al., "Long-term no-tillage direct seeding mode for water-saving and drought-resistance rice production in rice-rapeseed rotation System," Rice Science, vol. 21, no. 4, pp. 210-216, 2014.

[12] A. Bot and J. Benites, "The importance soil organic matter: key to drought-resistant soil sustained food production," FAO Soils Bulletin, vol. 80, 2005.

[13] J. Balesdent, "Un point sur l'évolution des réserves organiques des sols de Franc," Etude et Gestion des Sols, vol. 3, no. 4, pp. 245-260, 1996.

[14] T. Nishigaki, M. Shibata, S. Sugihara, A. D. Mvondo-Ze, S. Araki, and S. Funakawa, "Effect of mulching with vegetative residues on soil water erosion and water balance in an oxisol 
cropped by cassava in east cameroon," Land Degradation and Development, 2016.

[15] A. Nawaz, R. Lal, R. K. Shrestha, and M. Farooq, "Mulching affects soil properties and greenhouse gas emissions under longterm no-till and plough-till systems in alfisol of central Ohio," Land Degradation and Development, 2016.

[16] S. B. Mwango, B. M. Msanya, P. W. Mtakwa, D. N. Kimaro, J. Deckers, and J. Poesen, "Effectiveness of mulching under miraba in controlling soil erosion, fertility restoration and crop yield in the Usambara Mountains, Tanzania," Land Degradation \& Development, vol. 27, no. 4, pp. 1266-1275, 2016.

[17] M. N. Jiménez, E. Fernández-Ondoño, M. Á. Ripoll, J. CastroRodríguez, L. Huntsinger, and F. B. Navarro, "Stones and organic mulches improve the Quercus Ilex L. Afforestation success under mediterranean climatic conditions," Land Degradation and Development, vol. 27, no. 2, pp. 357-365, 2016.

[18] M. Prosdocimi, P. Tarolli, and A. Cerdà, "Mulching practices for reducing soil water erosion: a review," Earth-Science Reviews, vol. 161, pp. 191-203, 2016.

[19] M. Prosdocimi, A. Jordán, P. Tarolli, S. Keesstra, A. Novara, and A. Cerdà, "The immediate effectiveness of barley straw mulch in reducing soil erodibility and surface runoff generation in Mediterranean vineyards," Science of the Total Environment, vol. 547, pp. 323-330, 2016.

[20] F. Bessam and R. Mrabet, "Long-term changes in soil organic matter under conventional tillage and no-tillage systems in semiarid Morocco," Soil Use and Management, vol. 19, no. 2, pp. 139-143, 2003.

[21] R. Mrabet, "Effects of residue management and cropping systems on wheat yield stability in a semiarid mediterranean clay soil," American Journal of Plant Science, vol. 2, pp. 202-216, 2011.

[22] R. Moussadek, R. Mrabet, P. Zante et al., "Effets du travail du sol et de la gestion des résidus sur les propriétés du sol et sur l'érosion hydrique d'un Vertisol Méditerranéen," Canadian Journal of Soil Science, vol. 91, no. 4, pp. 627-635, 2011.

[23] J. Sheehy, K. Regina, L. Alakukku, and J. Six, "Impact of notill and reduced tillage on aggregation and aggregate-associated carbon in Northern European agroecosystems," Soil \& Tillage Research, vol. 150, pp. 107-113, 2015.

[24] A. Kassam, T. Friedrich, R. Derpsch et al., "Conservation agriculture in the dry Mediterranean climate," Field Crops Research, vol. 132, pp. 7-17, 2012.

[25] R. Moussadek, R. Mrabet, R. Dahan, A. Zouahri, M. El Mourid, and E. V. Ranst, "Tillage System Affects Soil Organic Carbon Storage and Quality in Central Morocco," Applied and Environmental Soil Science, vol. 2014, Article ID 654796, 8 pages, 2014.

[26] K. Kuotsu, A. Das, R. Lal, G. C. Munda, P. K. Ghosh, and S. V. Ngachan, "Land forming and tillage effects on soil properties and productivity of rainfed groundnut (Arachis hypogaea L.)rapeseed (Brassica campestris L.) cropping system in northeastern India," Soil and Tillage Research, vol. 142, pp. 15-24, 2014.

[27] R. Mrabet, No-tillage Systems for Sustainable Dryland Agriculture in Morocco, INRA Publication, Rabat, Morocco, 2008.

[28] D. W. Nelson and L. E. Sommers, "Total carbon, organic carbon and organic matte," in Methods of Soil Analysis, Part 2, Chemical and Microbiological Properties, Agronomy Monograph, A. L. Page, R. H. Miller, and D. R. Keeney, Eds., vol. 9, pp. 539579, American Society of Agronomy, Madison, Wis, USA, 2nd edition, 1982.
[29] W. B. McGill and C. T. Figueiredo, "Total nitrogen," in Soil Sampling and Methods of Analysis, M. R. Carter, Ed., pp. 201211, Canadian Society of Soil Science/Lewis Publishers, 1993.

[30] R. B. Grossman and T. G. Reinsch, "Bulk density and linear extensibility," in Methods of Soil Analysis: Part 4, Physical Methods, J. H. Dane and G. C. Topp, Eds., SSSA Book Series, pp. 201-228, Soil Science Society of America, Madison, Wis, USA, 2002.

[31] Y. Le Bissonnais, "Aggregate stability and assessment of soil crustability and erodibility: I. Theory and methodology," European Journal of Soil Science, vol. 47, no. 4, pp. 425-437, 1996.

[32] M. Laghrour, R. Moussadek, A. A. Zouahri et al., "Impact of no tillage on physical proprieties of a clay soil in central Morocco," Journal of Materials and Environmental Science, vol. 6, no. 2, pp. 391-396, 2015.

[33] D. A. Angers, M. A. Bolinder, M. R. Carter et al., "Impact of tillage practices on organic carbon and nitrogen storage in cool, humid soils of eastern Canada," Soil and Tillage Research, vol. 41, no. 3-4, pp. 191-201, 1997.

[34] H. Blanco-Canqui and R. Lal, "No-tillage and soil-profile carbon sequestration: an on-farm assessment," Soil Science Society of America Journal, vol. 72, no. 3, pp. 693-701, 2008.

[35] J. Hassink, "The capacity of soils to preserve organic C and N by their association with clay and silt particles," Plant and Soil, vol. 191, no. 1, pp. 77-87, 1997.

[36] X. H. Shi, X. M. Yang, C. F. Drury, W. D. Reynolds, N. B. McLaughlin, and X. P. Zhang, "Impact of ridge tillage on soil organic carbon and selected physical properties of a clay loam in southwestern Ontario," Soil and Tillage Research, vol. 120, pp. $1-7,2012$.

[37] M. M. Wander, M. G. Bidart, and S. Aref, "Tillage impacts on depth distribution of total and particulate organic matter in three Illinois soils," Soil Science Society of America Journal, vol. 62, no. 6, pp. 1704-1711, 1998.

[38] J. G. Guzman, C. B. Godsey, G. M. Pierzynski, D. A. Whitney, and R. E. Lamond, "Effects of tillage and nitrogen management on soil chemical and physical properties after 23 years of continuous sorghum," Soil and Tillage Research, vol. 91, no. 1-2, pp. 199-206, 2006.

[39] S. D. Sparrow, C. E. Lewis, and C. W. Knight, "Soil quality response to tillage and crop residue removal under subarctic conditions," Soil and Tillage Research, vol. 91, no. 1-2, pp. 15-21, 2006.

[40] D. A. Angers and N. S. Eriksen-Hamel, "Full-inversion tillage and organic carbon distribution in soil profiles: a metaanalysis," Soil Science Society of America Journal, vol. 72, no. 5, pp. 1370-1374, 2008.

[41] S. P. Syswerda, A. T. Corbin, D. L. Mokma, A. N. Kravchenko, and G. P. Robertson, "Agricultural management and soil carbon storage in surface vs. deep layers," Soil Science Society of America Journal, vol. 75, no. 1, pp. 92-101, 2011.

[42] E. Liu, S. G. Teclemariam, C. Yan et al., "Long-term effects of no-tillage management practice on soil organic carbon and its fractions in the northern China," Geoderma, vol. 213, pp. 379384, 2014.

[43] T. R. Paton, "Origin and terminology for gilgai in Australia," Geoderma, vol. 11, no. 3, pp. 221-242, 1974.

[44] I. Kovda, E. Morgun, and D. Tessier, "Etude de Vertisols à gilgai du Nord-Causcas: mécanismes de differenciation et aspects pédogeochimiques," Etude et Gestion des Sols, vol. 3, no. 1, pp. 41-52, 1996. 
[45] R. Mrabet, "Stratification of soil aggregation and organic matter under conservation tillage systems in Africa," Soil and Tillage Research, vol. 66, no. 2, pp. 119-128, 2002.

[46] A. S. Nascente, Y. C. Li, and C. A. Costa Crusciol, "Cover crops and no-till effects on physical fractions of soil organic matter," Soil \& Tillage Research, vol. 130, pp. 52-57, 2013.

[47] B. Dimassi, B. Mary, R. Wylleman et al., "Long-term effect of contrasted tillage and crop management on soil carbon dynamics during 41 years," Agriculture, Ecosystems and Environment, vol. 188, pp. 134-146, 2014.

[48] V. M. Testa, L. A. J. Teixeira, and J. Mielniczuk, "Cararcteristicas quimicas de um Podzolico Vermelho-escuro afetadas por sistemas de culturas," Revista Brasileira de Ciência do Solo, vol. 16, pp. 107-114, 1992.

[49] A. Pavinato, Teores de Carbono e Nitrogenio do Solo e Productividade de Milho Afetados por Sistemas de Cultura de Mestrado em Ciencia do Solo, PPG-Agronomia, UFRGS, Porto Alegre, Brazil, 1993.

[50] M. L. Burle, J. Mielniczuk, and S. Focchi, "Effect of cropping systems on soil chemical characteristics, with emphasis on soil acidification," Plant and Soil, vol. 190, no. 2, pp. 309-316, 1997.

[51] R. Mrabet, N. Saber, A. El-Brahli, S. Lahlou, and F. Bessam, "Total, particulate organic matter and structural stability of a Calcixeroll soil under different wheat rotations and tillage systems in a semiarid area of Morocco," Soil and Tillage Research, vol. 57, no. 4, pp. 225-235, 2000.

[52] H. Zhang, Y. Zhang, C. Yan, E. Liu, and B. Chen, "Soil nitrogen and its fractions between long-term conventional and no-tillage systems with straw retention in dryland farming in northern China," Geoderma, vol. 269, pp. 138-144, 2016.

[53] J. Diekow, J. Mielniczuk, H. Knicker, C. Bayer, D. P. Dick, and I. Kögel-Knabner, "Soil C and N stocks as affected by cropping systems and nitrogen fertilisation in a southern Brazil Acrisol managed under no-tillage for 17 years," Soil and Tillage Research, vol. 81, no. 1, pp. 87-95, 2005.

[54] E. Ouédraogo, A. Mando, and L. Stroosnijder, "Effects of tillage, organic resources and nitrogen fertiliser on soil carbon dynamics and crop nitrogen uptake in semi-arid West Africa," Soil and Tillage Research, vol. 91, no. 1-2, pp. 57-67, 2006.

[55] T. Yamashita, H. Flessa, B. John, M. Helfrich, and B. Ludwig, "Organic matter in density fractions of water-stable aggregates in silty soils: effect of land use," Soil Biology and Biochemistry, vol. 38, no. 11, pp. 3222-3234, 2006.

[56] Y. Lou, M. Xu, X. Chen, X. He, and K. Zhao, "Stratification of soil organic $\mathrm{C}, \mathrm{N}$ and $\mathrm{C}: \mathrm{N}$ ratio as affected by conservation tillage in two maize fields of China," Catena, vol. 95, pp. 124-130, 2012.

[57] M. Mazzoncini, D. Antichi, C. Di Bene, R. Risaliti, M. Petri, and E. Bonari, "Soil carbon and nitrogen changes after 28 years of no-tillage management under Mediterranean conditions," European Journal of Agronomy, vol. 77, pp. 156-165, 2016.

[58] M. Belmekki, M. El Gharous, O. EL Gharras, M. Boughlala, O. Iben Halima, and B. Bencharki, "Tillage effects on basic properties of an calcaeous soil under moroccan semi-arid climate," International Journal of Advanced Research in Engineering \& Technology, vol. 5, no. 3, pp. 130-146, 2014.

[59] L. C. Kibet, H. Blanco-Canqui, and P. Jasa, "Long-term tillage impacts on soil organic matter components and related properties on a typic argiudoll," Soil \& Tillage Research, vol. 155, pp. 78-84, 2016.

[60] E. Amézketa, "Soil aggregate stability: a review, Journal of Sustainable Agriculture, vol. 14, no. 2-3, pp. 83-151, 1999.
[61] M. R. Carter, "Characterizing the soil physical condition in reduced tillage systems for winter-wheat on a fine sandy loam using small cores," Canadian Journal of Soil Science, vol. 72, no. 4, pp. 395-402, 1992.

[62] R. J. Haynes and G. S. Francis, "Changes in microbial biomass C, soil carbohydrate composition and aggregate stability induced by growth of selected crop and forage species under field conditions," European Journal of Soil Science, vol. 44, no. 4, pp. 665-675, 1993.

[63] D. A. Angers, L. M. Edwards, J. B. Sanderson, and N. Bissonnette, "Soil organic matter quality and aggregate stability under eight potato cropping sequences in a fine sandy loam of Prince Edward Island," Canadian Journal of Soil Science, vol. 79, no. 3, pp. 411-417, 1999.

[64] J. Six, E. T. Elliott, and K. Paustian, "Aggregate and soil organic matter dynamics under conventional and no-tillage systems," Soil Science Society of America Journal, vol. 63, no. 5, pp. 13501358, 1999.

[65] N. Bissonnette, D. A. Angers, R. R. Simard, and J. Lafond, "Interactive effects of management practices on water-stable aggregation and organic matter of a Humic Gleysol," Canadian Journal of Soil Science, vol. 81, no. 5, pp. 545-551, 2001.

[66] M. R. Carter, "Soil quality for sustainable land management: organic matter and aggregation interactions that maintain soil functions," Agronomy Journal, vol. 94, no. 1, pp. 38-47, 2002.

[67] R. Lal, "Soil structure and sustainability," Journal of Sustainable Agriculture, vol. 1, no. 4, pp. 67-92, 1991.

[68] M. T. de Moraes, H. Debiasi, R. Carlesso, J. C. Franchini, V. R. da Silva, and F. B. da Luz, "Soil physical quality on tillage and cropping systems after two decades in the subtropical region of Brazil," Soil \& Tillage Research, vol. 155, pp. 351-362, 2016. 

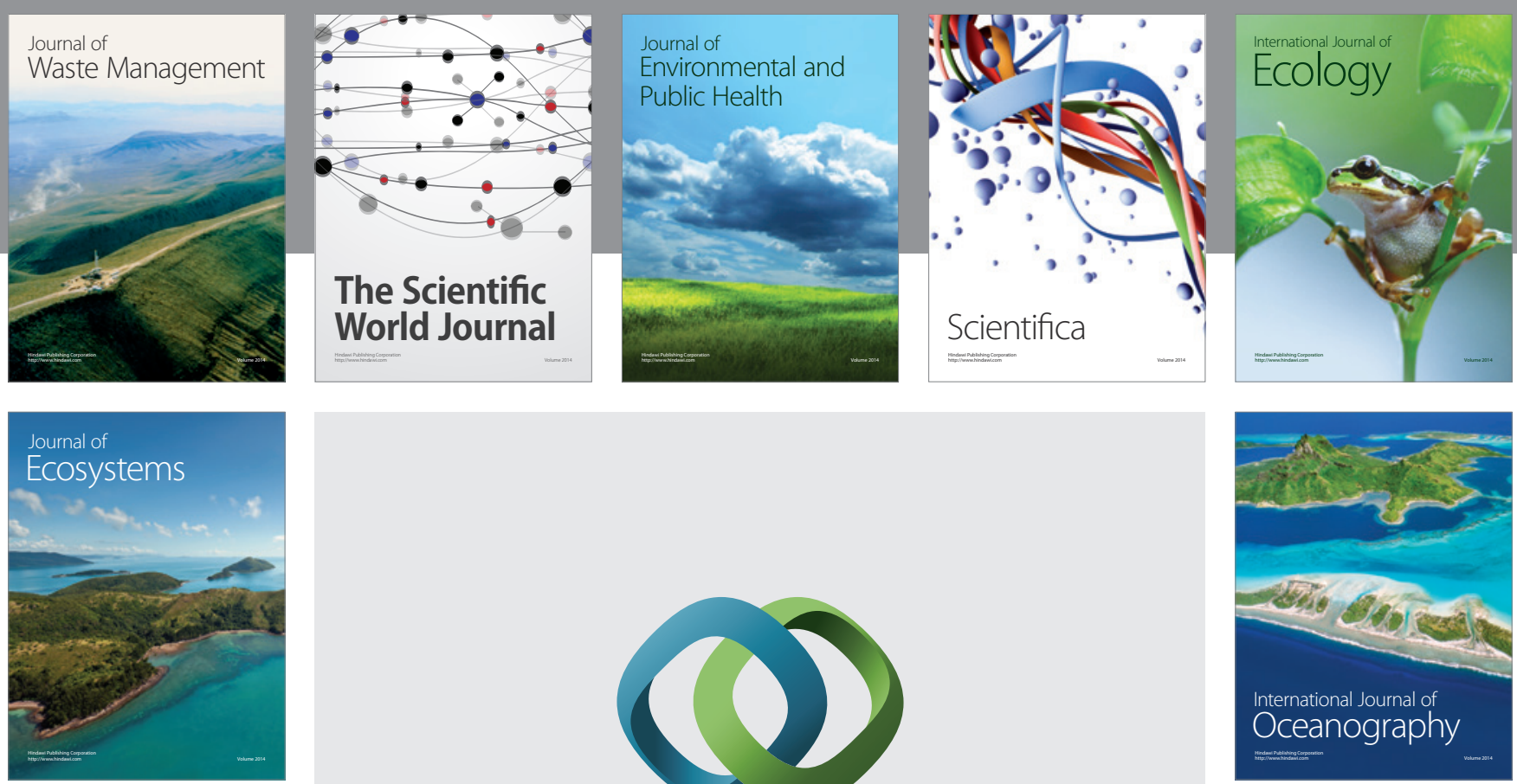

The Scientific World Journal
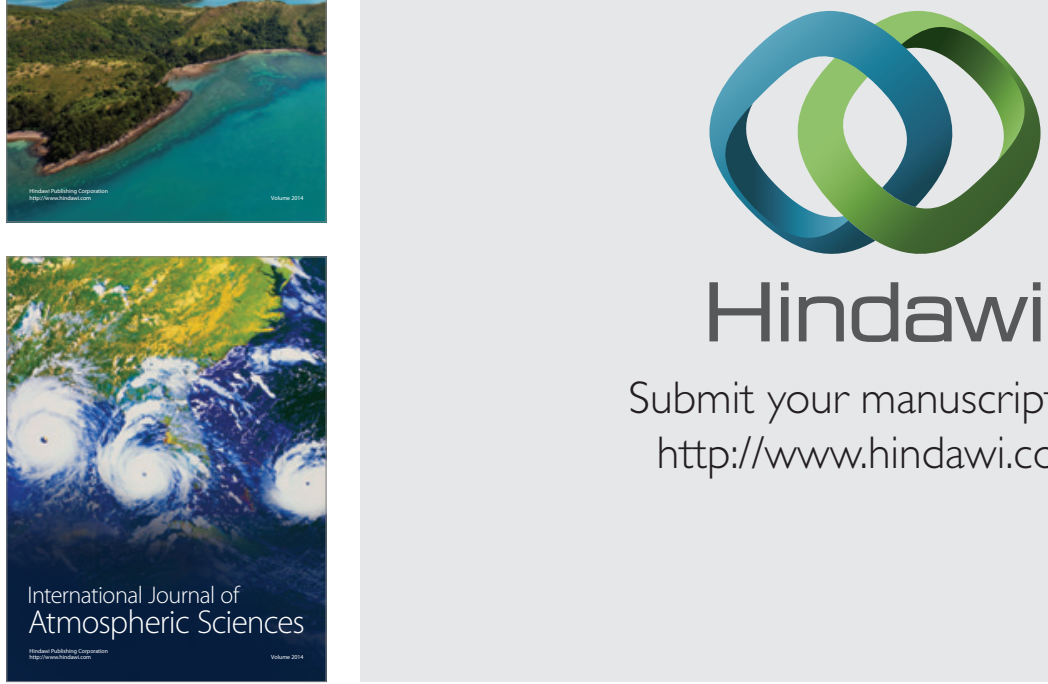

\section{Hindawi}

Submit your manuscripts at

http://www.hindawi.com
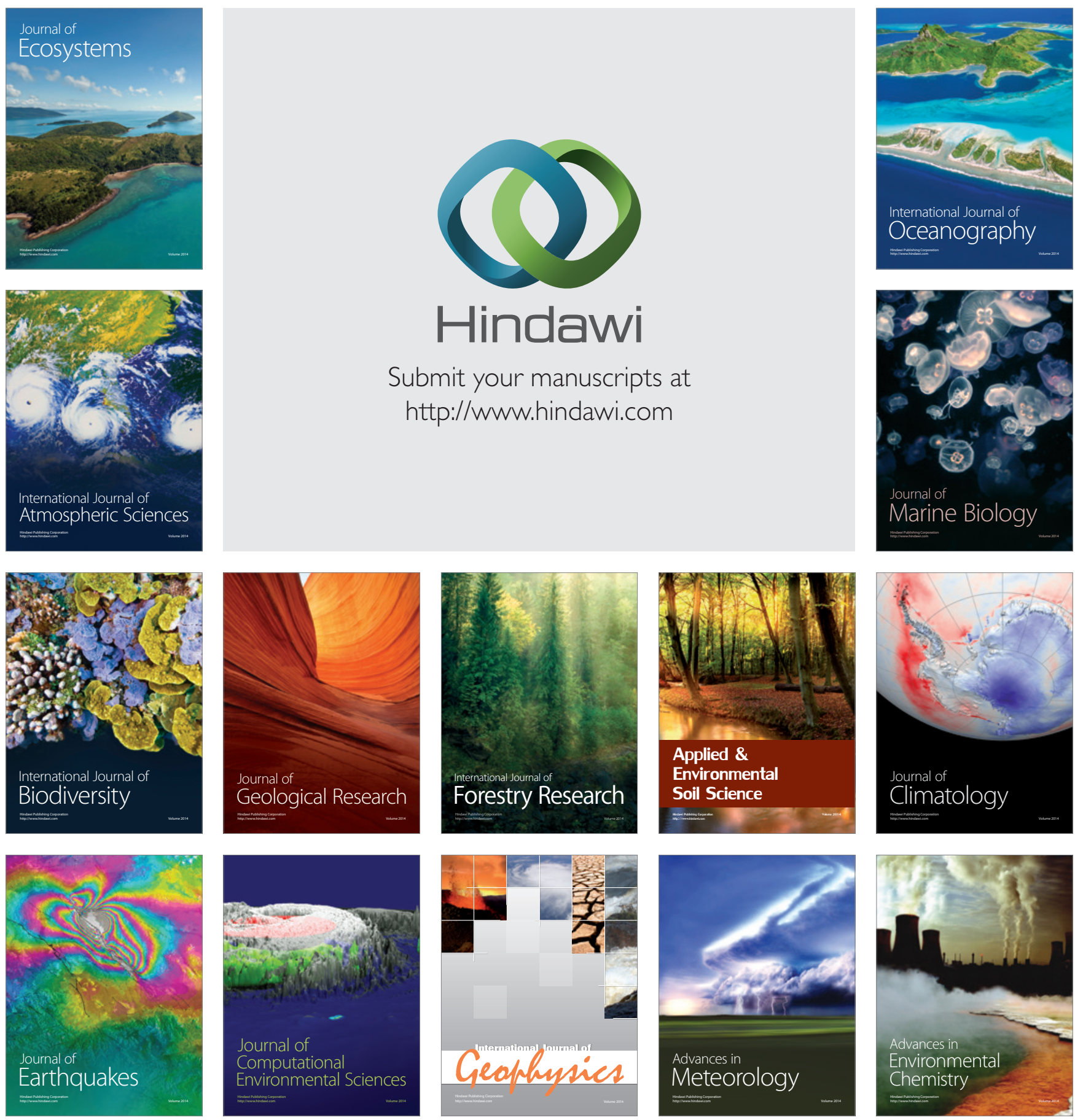